Mariusz Szuster

Poznan School of Logistics

e-mail: mariusz.szuster@wsl.com.pl

\title{
GEOPOLITICAL DIMENSION OF BUILDING THE NEW SILK ROAD
}

\begin{abstract}
Background: The trade war between the United States and China has fueled the discussion about the legitimacy of implementing a major project called the New Silk Road. For many countries, this project is an opportunity for development. The logistics industry should also benefit. However, the huge scale of the project raises some concerns and the suspicion that the New Silk Road project is only to a small extent to have a positive effect on trade between China and other countries along this route. Fears arise that the transport and logistics facilitation of doing business between the countries concerned are just a cover for the hidden purposes of building Chinese hegemony in the world.

Methods: A descriptive method was used, supported by graphic elements. The most important secondary data on investment rate and trade between China and Europe were shown, taking into account the use of various modes of transport.
\end{abstract}

Results: A set of official and unofficial goals of project implementation was presented. Similarly potential threats to participants of this project were presented. It has been confirmed that improving transport and communication connections is only part of the entire investment plan.

Conclusions: Despite many advantages perceived at the microeconomic level (facilitation for companies looking for a transport alternative to the two leading transport sectors between China and Europe: sea and air), there are many areas that raise serious doubts. The analysis of the benefits that European companies can obtain shows many limitations. On the other hand, the Chinese government benefits from the project in many areas, also (and maybe even above all) non-economic. The fact is that hundreds of billions of dollars have been invested in infrastructure projects. This confirms the momentous importance of the project.

Keywords: international trade, infrastructure investments. 


\section{INTRODUCTION}

The New Silk Road (NSR) is a Chinese initiative, which restores dating back to antiquity idea of economic and trade exchange between China, the Middle East and Europe. The project includes, among others, the creation of new transport corridors from China to Europe. Generally, it is a variety of infrastructural facilities (railways, sea ports, roads, telecommunications lines, pipelines), which are to connect the Far East with the Middle East and Europe. The proposed network of transport links refers to the historic Silk Road. Ancient trade route had been linking China to the Middle East and Europe. The history of the Silk Road dates back to the 2nd century BC. It was established during the Han dynasty and it allowed merchants to travel between the East and the West. The Chinese Han dynasty initiated the creation of the Silk Road in 138 BC, sending emissaries to distant lands [Chen and Liang 2018]. The Ancient Silk Road began in the then capital of the Chinese Empire - Chang'an (today's Xi'an), going through the outskirts of the Takla Makan desert it reached Persia and Europe, connecting China, India, Persia, Arabia, Egypt and Rome. The Ancient Silk Road ran 15,000 km between the old capital city of China and the Roman Empire [Lin 2011]. Commodities such as silks, gems, gold, silver, carpets, tea, paper, spices were transported along this route on camels or donkeys [Otsuka 2001]. As Marco Polo recorded in the late 13th century, it took him four years to travel along the entire Ancient Silk Road by foot [Woods 2015]. This route until the 17th century had been connecting China with the Middle East and Europe. In the 17th century, as European voyagers thrived the maritime trading route, this land route faded out due to its overall longer transport time [Otsuka 2001]. Today Chinese government wants to establish economic and political relations with societies located west of China. The emerging Eurasian land bridge revives the Ancient Silk Road as a land route (mainly by railway) for trading between The East and The West [Schramm and Zhang 2017].

\section{TERRITORIAL AND LOGISTICAL DIMENSIONS OF THE NEW SILK ROAD}

The New Silk Road is not simple one direct road, but the entire network of routes. The concept assumes the construction of new communication and trade connections in countries along the emerging Eurasian corridor. This great investment program involves the construction of a network of sea and land infrastructure facilities, especially railways, as well as other investments in countries along the route. It includes not only railways or port projects, but also cross-land connections such as pipeline construction and even internet networks [Liu and $\mathrm{Ke}$ 
2018]. But still the key aspect is the development of transport infrastructure; high-speed railways, port facilities, roads and highways. Generally, it includes modernization of existing railroads and the construction of new railways and other roads within the shaped in this way corridor. For example for a loan from Beijing two airports, a sea port, an oil terminal and a road will be built in Djibouti (east Africa), tourist infrastructure, including the airport, will be developed in the Maldives (located southwest of Sri-Lanka). In Laos, a Chinese rail link will be built for Chinese money, Mongolia is building a hydroelectric power station and a highway, and Tajikistan and Kyrgyzstan will have a gas pipeline [Kalwasiński 2018]. The Chinese government plans to build new or modernize existing railway lines from China to Singapore, as well as from China to Bangladesh, Pakistan, India, Iran, and further to Turkey and European countries. This initiative deals with the development of the infrastructure connecting China with other countries from three continents. It is designed to build a new Eurasian bridge from China through Central Asia towards Europe and Africa. Due to the large scale and considerable number of participants, this project is called in many different ways depending on the author's or speakers intentions, the project is named differently. New Silk Road (新丝绸之路) is sometimes called One Belt, One Road (OBOR) (一带一路), New Silk Road Economic Belt ( 丝绸之路经济带和), $21^{\text {st }}$ Century Maritime Silk Road (21世纪海上丝绸之路) [Tomański 2019]. In papers published in English it is often called Belt and Road (B\&R) or Belt and Road Initiative (BRI). In September 2013, General Secretary (also named Chinese President) Xi Jinping during his visit in Kazakhstan expounded the idea of the "New Silk Road Economic Belt" [Chen and Liang 2018]. Xi Jinping recalled the history of Ancient Silk Road in a speech at the Kazakh University of Nazarbaev, proposing the creation of an economic initiative of the "New Silk Road" running from Western China through Central Asia to Europe. One month later, addressing Indonesian Parliament, Xi proposed to create a complementary "Maritime Silk Road" to expand maritime connections and cooperation platform between China and Southeast Asia. In result, the NSR includes two major parts - the New Silk Road Economic Belt and the $21^{\text {st }}$ Century Maritime Silk Road [Schramm and Zang 2018]. In the literal translation of the term "Belt and Road", belt means land corridors created for the routing of railway lines from China to Europe, while the road is not a literal road, because it concerns sea connections. The land belt will connect China with Central Asia and Europe. The sea road means connecting the Far East with the Middle East, Africa and Europe. The sea route is currently in use, but NSR is mainly about giving it a new dimension. The Maritime Road emphasizes improving 
connectivity with Southeast Asia, South Asia, West Asia, Europe and Africa, by developing a network of ports and other facilities along the Maritime Road. The sea route applies to a network of ports drawn in parallel with the road, ranging from the east coast of China through Indochina, Pakistan, India, Sri Lanka, the countries of the Persian Gulf to Venice and Piraeus. In Venice it converges with the European transport network. The Maritime Silk Road begins in Quanzhou (Fujian) and goes to other southern Chinese ports before heading to the Malacca Strait. From that point the Maritime Silk Road heads to Kolkata, then crosses the rest of the Indian Ocean hits into the Mediterranean Sea - with a final stop in Greece or Italy [Brugier 2014]. The sea corridor runs through several neighboring sea zones - the South China Sea, the South Pacific and the Indian Ocean. East Africa is an important part of this route. For some time now, the Chinese interest in the region has been noticeable, as well as great Chinese investments realized in Africa.

The New Eurasian Land Bridge originally spans from the pacific port of Lianyungang in China running through Kazakhstan, Russian Federation, Belarus to Rotterdam in the Netherlands with a variety of intermodal terminals as points of origin and destination in between [Schramm and Zhang 2018]. For the land route, two options are the most prospective: the north route and the central route. The route proposed years ago through Ukraine due to the military conflict in Donbass is currently not taken into account. 


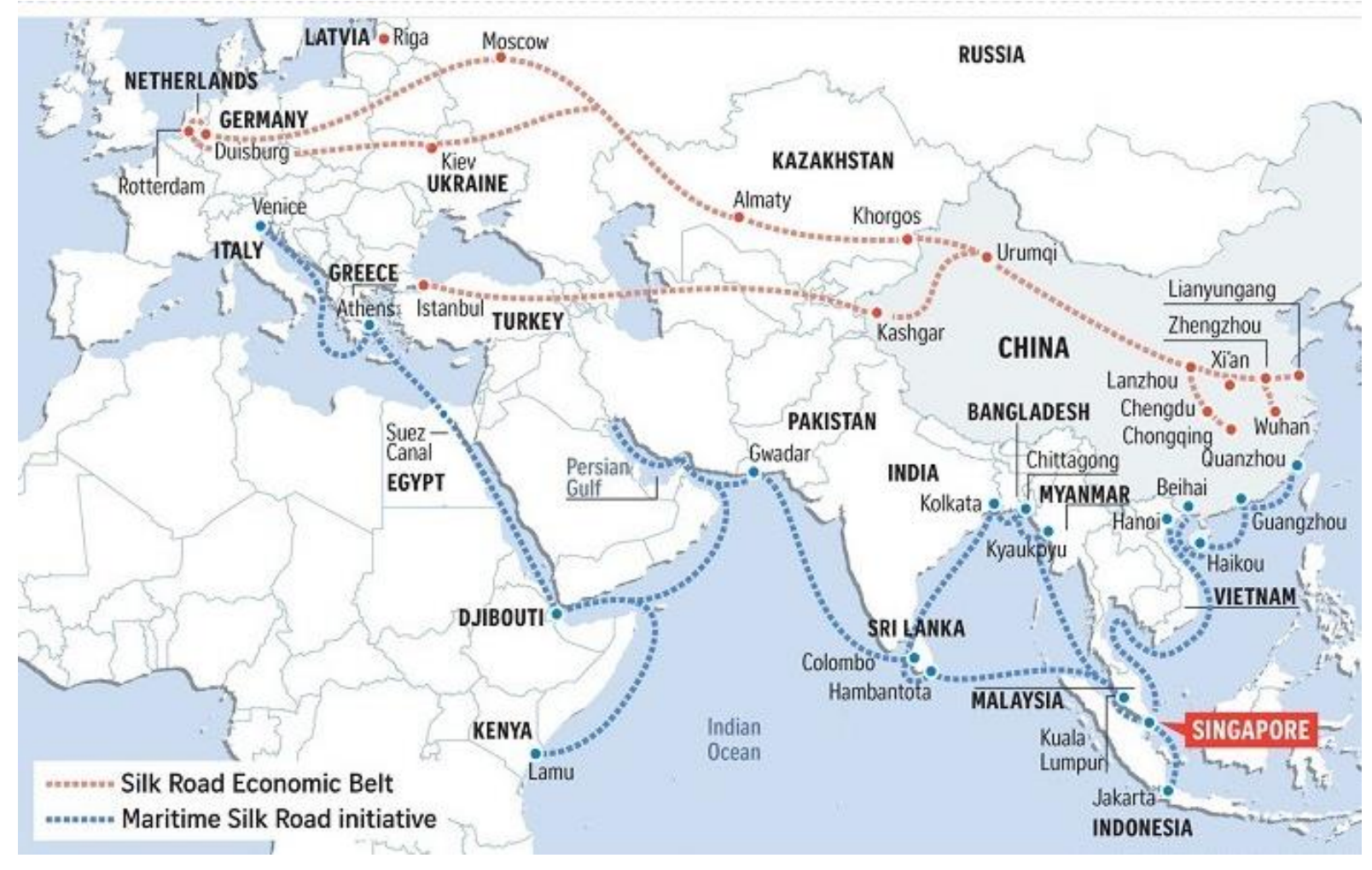

Fig. 1. The main routes on the New Silk Roads. Source: Straits Times Geographics.

The Northern Corridor covers the Russian Trans-Siberian Railway (TSR), through Kazakhstan, Russia, in the last phase it reaches the territory of Belarus, Poland and Germany (Kazakh route). This corridor is currently most intensive used. Its advantage is that it passes through the territories of the smallest number of countries, and thus exceeds the smallest number of border crossings. The downside are the harsh climatic conditions along its route and the passage through Russia, which is a strong and potentially claims-making partner for China. There are two other variants of the Northern Corridor; second through Mongolia, and third through Russian Far East. Second from China goes by TSR via Erenhot/Zamyn-Uud and transit through Mongolia (Mongolian route), and third from China by TSR via Manzhouli/Zabajkalsk (Manchurian route) [Galushko 2016]. TSR heads toward west and enter European Union at Brest/Małaszewicze, Chop/Dobra or (but to much less extent) via Estonia, Latvia, Lithuania, and/or the Russian exclave of Kaliningrad [Schramm and Zhang 2018]. However, it is noted that the classic TSR line starting in Vladivostok (eventually in Nachodka) is not considered in the NSR development strategy [Sárvári and Szeidovitz, 2016]. The alternative Central Asian railway route may go through southern Kazakhstan and reach Europe via the Middle East countries, instead of via Russia. The Central Corridor would allow (if necessary) to bypass 
Russia completely. The Central Corridor - also called the Trans-Caspian International Transport Route (TITR), crosses the area of Kazakhstan, then reach the Azerbaijani port of Alat, then pass through the Caspian Sea, southern Caucasus and goes to Europe through Turkey. Its main disadvantage is the diversity of transport forms and political uncertainty in the Caucasus. These multiple border crossings, ferry trips and current geopolitical situation in the Caucasus region make it rather unattractive at present [Schramm and Zhang 2018]. As a result, despite the fact that the Central Corridor is shorter, using it does not translate into time saving. The Northern Route is about 12,920 km and takes 22 days, while the Trans-Caspian route from eastern China to Istanbul is $10,650 \mathrm{~km}$ but it similarly takes 21-23 days [Liu and Ke 2018]. The Southern Corridor through Iran is also possible. After stretching to the border with Kazakhstan the New Silk Road heads southwest to Iran before passing through Iraq, Syria and Turkey, it crosses then the Bosphorus and heads to Europe (finally to Germany and Rotterdam in the Netherlands) [Brugier 2014]. However, due to geopolitical reasons and the threat of war it is treated as the most risky.

For many countries, the possibility of obtaining economic support from China is very attractive. Central Asian governments, for example in Kazakhstan, hope that the modernization of infrastructure will contribute to further development [Barisitz and Radzyner 2017]. Since February 2016, for example China and Iran have also been linked (via Kazakhstan and Turkmenistan) by freight trains. The Khorgos-East Gate is built as a dry port at the border between China and Kazakhstan. The project includes large scale logistics and industrial zones of 5,740 hectares. Approximately 65 trains, amounting to 6,200 TEU, per month are currently being transshipped through Khorgos Gateway [Schramm and Zhang 2018]. The special location of Khorgos makes it the key dry ports for handling trans-Eurasian trains. Khorgos-East Gate is a wholly owned subsidy of Kazakhstan's national railway, but is also receiving investment from various sources, including China OBOR funds. For example, China's Jiangsu province has signed an agreement with the Kazakhstan government to invest USD 600 million into this project [Schramm and Zhang 2018]. A growing number of countries and organizations are giving their acknowledgement and support to the initiative [Li 2018]. Initial interest in participating in the project was expressed by governments and representatives of around 70 countries and regions, which together constitute $40 \%$ of global GDP and $60 \%$ of the world's population [Liu and Ke 2018]. The reason is the fact that this initiative is far from an empty vision. China is investing heavily in the project [Lain 2018]. The Beijing government plans to 
spend USD 900 billion on infrastructure projects and since 2013, USD 304.9 billion in contracts have been signed between China and the economies along the route [Lain 2018]. Project cofinancing is implemented, among others through the state-owned banks of the Chinese Development Bank and Chinese Export-Import Bank. In 2017, it was assumed that the whole plan could amount to as much as USD 900 billion, and that every year China will be able to start projects worth USD 150 billion. The gigantic investments translated into dynamic growth in the sphere of rail transport. In 2006, the train travel time from China to Europe was 47 days, now it is several days [Schramm and Zhang 2018]. This was possible due to, among others, considerable Chinese infrastructure investments. 13-15 years ago the Eurasian rail freight could take only a small share of the total transport volume between China and Europe. Nowadays, a rapid growth of freight transport on the rail routes along the Belt is visible.

Table 1. Rail container trade between China and Europe in TEU.

\begin{tabular}{|l|l|l|c|c|c|c|}
\hline 2011 & 2012 & 2013 & 2014 & 2015 & 2016 & 2017 \\
\hline 1.404 & 3.674 & 6.960 & 26.070 & 68.902 & 145.794 & 317.930 \\
\hline
\end{tabular}

Source: [Liu and Ke 2018].

Chinese authorities report that in 2018 even 450.000 TEU were transported by rail through the New Silk Road. According to their forecasts, trains will transport 1 million TEU on this route in about 10 years [Luo 2017]. Since 2011, a train, the Trans-Eurasia-Express, regularly conveys valuable merchandise, e.g. computers, other electronic equipment, automotive and machinery parts, raw materials for industry and garments from central China to Duisburg. On their way back to China, these trains carry European car parts, wine, whiskey, chocolate, pharmaceuticals and other precious goods [Barisitz and Radzyner 2017].

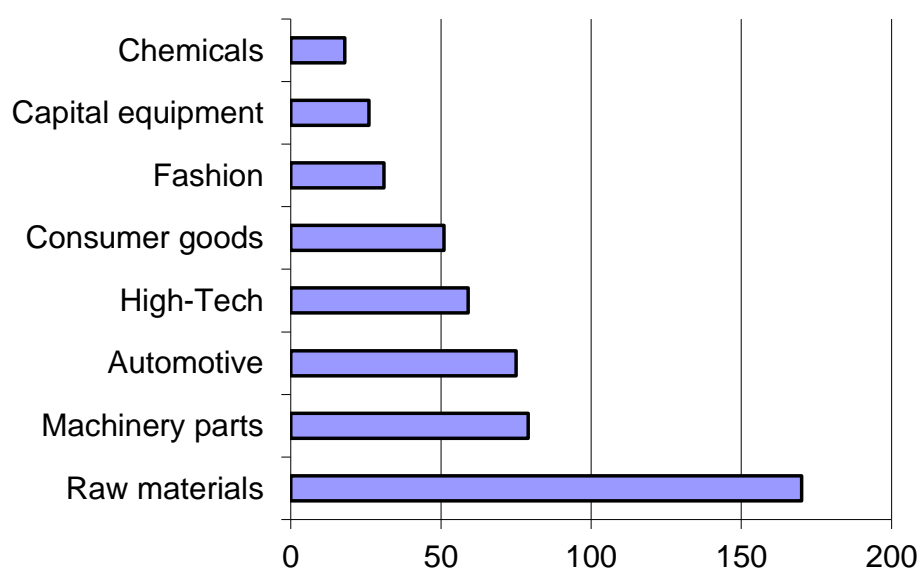

Fig. 2. China-Europe rail volumes (in 1000 tons).

Source: Economist. 
Table 2. Route competition for container shipment from Shanghai to Duisburg.

\begin{tabular}{|c|c|c|c|}
\hline Mode & Route & Transit Time & Cost USD $(15$ tons $60 \mathrm{cbm})$ \\
\hline sea & $\begin{array}{c}\text { Shanghai - Hamburg }- \\
\text { Duisburg }\end{array}$ & $30-35$ days & $1.700-2.900$ \\
\hline rail & Shanghai - Duisburg & $18-19$ days & $5.000-5.600$ \\
\hline air & Shanghai - Duisburg & $3-7$ days & $27.500-29.800$ \\
\hline
\end{tabular}

Source: [Liu and Ke 2018].

Today, most goods from China reach Europe by sea. This is the cheapest, but at the same time it lasts the longest. On average, transport by ship takes about a month. A bit more expensive, but half the option is rail transport. Railroads connecting China and Europe can reduce the number of days of shipment to an average of 14-15, compared to 30-35 days required by maritime transport [Barisitz S., Radzyner 2017]. In terms of transport costs, rail is regarded to be much cheaper than air transport. Therefore, with a speed advantage against sea and price advantage against air, Eurasian rail freight seems to fit a market niche in modern supply chains with great potential to grow its market share in the future. According to the fiveyear development plan issued by the Chinese National Development and Reform Commission, the number of trains is expected to reach 5,000 per year by 2020 [Luo 2017]. On the one side despite the dynamic development of rail transport, most goods on the New Silk Road are transported by sea, on the other it is a long-term and relatively new project, which is why this concept is constantly evolving and the scale of the project is growing.

For rail transport from China to Europe, the terminal in Małaszewicze, located in Poland $5 \mathrm{~km}$ from the border with Belarus, is of key importance. Over the past few years, it has recorded a rapid increase in the number of trains accepted. In 2018 there were 2.2 thousand, while in 2011 only 17. In 2018, over 98 percent. containers handled in Małaszewicze went from or to China. It is estimated that over 80 percent trains on the China-EU route passes through the Brest-Terespol border crossing and the so-called dry port in Małaszewicze. The revenue of the state budget from collected customs and tax receivables for the stream of import loads served by the Customs Department in Małaszewicze increased in 2018 to nearly PLN 3 billion. Czech Republic, Slovakia and Hungary also aspire to be the most important transit hub in Central and Eastern Europe. The government of the latter country has announced the construction of eight new nodes adapted to China-Europe rail freight traffic. In the case of Hungary investments planned to achieve this goal are worth over EUR 12 billion over the next five years. The purpose of these investments is to increase the logistic potential of the country. Optimal use of the possibilities of the New Silk Road is to help, among others electrification of the railway line 
from Hungary to Slovenia (Koper), modernization of the Budapest-Belgrade railway line (the project is financed by the Chinese government). All this is to ensure that goods transported by sea to Greece and Slovenia will be able to reach, via Hungary, West Europe. The road through the Kaliningrad Oblast is also a serious competition. The expansion of this corridor in terms of transit from China may even exclude Poland from participating in the New Silk Road.

The new Silk Road is to be ready by 2049. Currently, the attention of observers is focused on the development of road, rail, energy and maritime infrastructure. Further plans mention trade facilitation and investment, which will mean greater opportunities for Chinese companies to expand.

\section{OFFICIAL AND UNOFFICIAL OBJECTIVES OF THE NEW SILK ROAD INITIATIVE}

In May 2017, the first summit dedicated to the One Belt, One Road initiative was organized in China. Presidents and heads of governments of several European countries, Russia, Kazakhstan, Turkey and the USA, as well as representatives of the UN and the International Monetary Fund participated in this event. Chinese President Xi Jinping proposed the One Belt, One Road initiative for international cooperation. The President proposed the initiative, at the same time inviting companies and governments from three continents to cooperate [Li 2018]. President $\mathrm{Xi}$ announced that his ambition is a giant project, thanks to which such distant places like Nairobi and Rotterdam will be connected by land and sea routes with China. Total investments related to the One Belt, One Way project had been declared to amount from several hundred billion to even several trillion dollars [Adamczyk 2017]. During the first summit a thousand projects were announced to be launched in 49 countries. During the April 2019 second summit in Beijing on the Belt and Road Initiative, contracts were signed for the implementation of related projects totaling over USD 64 billion. According to the joint communiqué adopted at the end of the second summit, agreement was reached that funding for initiative projects must take into account global debt goals and promote environmentally friendly development. In a separate statement, the Chinese side announced the signing of memoranda of cooperation under NSR with various countries, including Italy, Luxembourg, Peru, Barbados and Jamaica.

The main goal of the One Belt, One Way initiative is to search for the most effective ways of transporting goods between continents. Currently, most of the transport of goods on the China-Europe route takes place by sea, which takes over a month. The new Silk Road will 
facilitate the transport of goods by shortening this period. Rail transport ensures traveling the China-Europe route in two weeks, and in addition is much cheaper than the fastest air transport. The construction of ports and related facilities will increase China's sea range through the Indian Ocean and, via the Suez Canal, to the Mediterranean. The sea, air and land routes of the New Silk Road are to complement each other. The next aims of the NSR are to establish and strengthen regional cooperation and partnerships among the countries along these routes, and to facilitate flow of economic resources and integration of markets [Song 2015]. A sea route of Maritime Silk Road is planned to support cooperation in Southeast Asia, Oceania and North Africa. Over time, the New Silk Road Economic Belt and the Silk Road Maritime will be able to intertwine with the anticipated China-Pakistan Economic Corridor and the BangladeshChina-India-Myanmar Economic Corridor.

According to the official position, the New Silk Road aims to strengthen economic cooperation between the countries along this route. The construction of new transport infrastructure facilities will certainly contribute to increasing trade and boosting economic cooperation between the countries and regions along the route. According to the declaration, the most important goal of the trail construction is to intensify international cooperation in the area of investment and trade. It is connected with the necessity to introduce facilitations in this area and elimination of barriers like procedures that slow down the transport of goods. The Chinese are aware that because of policy of Donald Trump the potential for further growth of trade with USA is much smaller than in recent years. For this reason, they are looking for new markets for their goods. The multifaceted development of connecting infrastructure is to enable increased trade between China and the huge Eurasian area west of China. Trade between China and the European Union is worth well over EUR 1 billion each day, with thousands of tons of goods being carried from one end of the Eurasian continent to the other - mostly by sea, along the vital lanes that connect Suez and Shanghai. But because of the sheer volume of trade, Chinese ports are increasingly clogged by an excess of outbound cargo destined for Europe [Brugier 2014]. In the same time about three-quarters of Chinese imports from Russia and 60\% of Chinese imports from Kazakhstan are carried out via the sea ports of St. Petersburg and Vladivostok, although both Russia and Kazakhstan are immediate neighbors of China and share more than $2000 \mathrm{~km}$ of common borders with China, because of the relatively modest level of logistical development of intra-Eurasian overland trade [Barisitz and Radzyner 2017]. It indicates vast connective potential for infrastructural projects in this area. 
Another point is connected with strategic energy and resource security issues. China's rapid economic growth and industrialization have increased the demand for energy to exceed domestic supply, leading to energy security concerns. Energy security is an important aspect of China's national security, and securing access to abundant oil supplies are one important element of its energy security strategy [Sheu and Kundu 2018]. Most China oil deliveries is supplied using oil tankers. Approximately 83\% of China's oil supplies are seaborne, of which around $80 \%$ come through the Strait of Malacca, which is a geopolitically disputed zone [Sheu and Kundu 2018]. The Strait of Malacca is between the Indian Ocean and the South China Sea. Moreover, $50 \%$ of natural gas and $43 \%$ of goods go through the sea routes on the Maritime Silk Road [Jiang et al., 2018]. The Chinese government has been aware of the dangers arising from the critical importance of the Malacca Strait between Malaysia and Indonesia. This geopolitical bottleneck could be closed by a military adversary in the case of conflict, which makes China potentially strategically vulnerable. China's dependence on shipments through the Strait of Malacca has already been partly reduced by the creation of land alternative, including the construction of pipelines from Central Asia and of corridors linking China directly to the Indian Ocean (via Pakistan and via Myanmar) [Barisitz and Radzyner 2017]. The OBOR initiative provides expected diversification, through the China-Pakistan economic corridor and the Myanmar-China oil pipeline [Sheu and Kundu 2018]. Land transportation corridors aim to eliminate the dilemma associated with the Strait of Malacca.

Another goal is related to the situation on the Chinese construction services market. Many Chinese enterprises have gained great experience in high-speed rail construction within the country and are looking to apply their expertise in projects abroad now. After many domestic infrastructure projects have been finished, Chinese infrastructure-related industrial and service sectors are saddled with overcapacities [Barisitz and Radzyner 2017]. This project is to lead to increased international demand for these resources. Moreover, a decrease in interest in rail transport services has recently been observed. In China, after many years of clear growth (from 2000 to 2012-2013), there was first stagnation and then a decrease in the number of transports. Only the intensive activities of the Chinese authorities connected with subsidizing rail transport improved the situation. However, it can be seen that the limit of four trillion metric tons is becoming an insurmountable barrier even despite the fact that the Chinese economy has grown by around 50\% during this time (according to official statistics). 


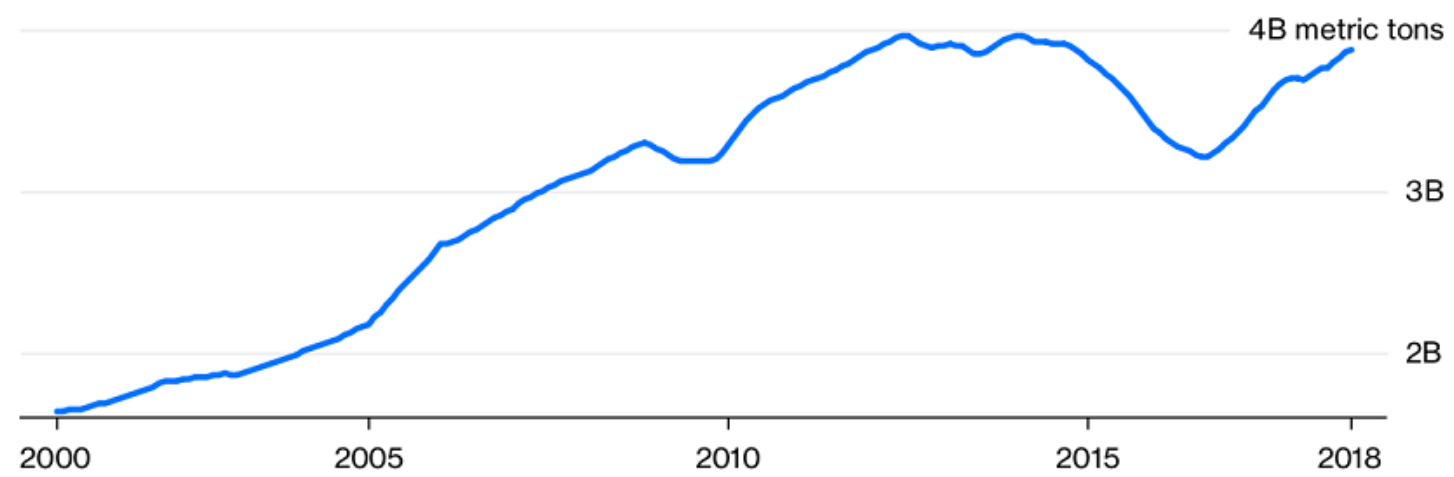

Fig. 3. Chinese rail traffic.

Source: Bloomberg.

The project is also the opportunity for the less developed central and western regions of China. While in recent decades mainly eastern regions have developed (located on the coast, from where the vast majority of goods were exported by sea), other regions have clearly lagged behind. This was mainly due to a simple logistic rule. Since the Chinese economy in the last 20 years has been directed at export possible mainly based on sea routes, manufacturing factories were located on the coast of China. Thanks to this, the route and time of transport carried out between factories and seaports servicing international goods exchange were shortened. Because NSR corridors are going through central or western part of China it is possible to transform the northwestern part of China. Infrastructural investments may open up opportunities for further investments in new factories and stepped-up economic activity in this remote region.

Less officially the Chinese authorities promote the use of the renminbi-yuan in international transactions. The aim is to expand the scope and scale of bilateral currency swaps and settlements with other countries along the NSR [Barisitz and Radzymer 2017]. Currency integration in the regions along the New Silk Road is a fact. The renminbi-yuan is ever more widely used in Kazakhstan, Mongolia, Uzbekistan, Thailand and Vietnam [Brugier 2014].

Finally, China is striving for a long-term transformation in the nature of contemporary international relations - from the system that is largely shaped by unipolar American domination to a multipolar world order. The NSR is a concept that is currently associated with all of China's efforts to build a strong (dominant) position on the international stage. This project could become a non-military catalyst that accelerates the relative decline in US hegemony in the world and contributes to a more balanced distribution of geopolitical influences. The NSR is more than just physical connections, however, it can be expected that China will benefit the most [Tian, 2016]. It provides a blueprint framework for Chinese diplomatic, commercial and foreign infrastructure investments and policies [Van der Putten and Meijnders 2015]. The 
Beijing initiative is primarily an important diplomacy tool. It helps to build a strong position of China in the world.

\section{RESERVATIONS ABOUT THE NEW SILK ROAD INITIATIVE}

The initiative raises doubts about China's strategic goals. One of the main assumptions of the New Silk Road is the expansion of the rail network through Eurasia, so that transport via this route becomes a serious alternative to maritime transport. Currently, the Eurasian rail freight only take a small share of the total transport volume between China and Europe. For now, it looks like it will take several decades to achieve this goal. Goods worth USD 330 million were sent to Europe in the first four months of 2018 via the rail freight terminal in Yiwu near Shanghai. That's a third of what a huge container ship can take. Through four major Chinese ports, such a quantity of goods passes every three hours [Kozieł 2018].

It is not even known what area actually Belt and Road project covers and will cover. The Chinese regularly update the concept, including not only Asia and the Pacific, Africa and Europe, but also South America and the Arctic [Kalwasiński 2018]. Currently, almost the entire world is within the scope of this project, except for the world powers reluctant to Beijing: USA, Japan and India.

Officially, its goal is to stimulate the development of international trade, but according to some critics, especially in the West, it serves the expansion of Chinese influence. China has been building its position as a global power for years, and the One Belt and One Road project is to strengthen it. The Chinese practice of granting credit guaranteed by the host country for an infrastructure project that is implemented by Chinese companies employing Chinese employees is perceived as dangerous. It may lead to political dependence of some weaker countries, e.g. Sri Lanka, Laos, Cambodia or even Greece. It may lead poorer countries to the "debt trap". In Tajikistan and Kyrgyzstan public debt will exceed or approach the limit of 60 percent of GDP and, at the same time, China's share in foreign debt will exceed 40 percent [Kalwasiński 2018].

China is the largest manufacturer and exporter in the world. Production in this country accounts for more than a quarter of world production. It leads to specific trend in economic relations with Europe. While the European markets are open to Chinese investors, European investors constantly beat their heads against the (Chinese) wall. The direct investments of European companies in China still face numerous (e.g. administrative) barriers. 


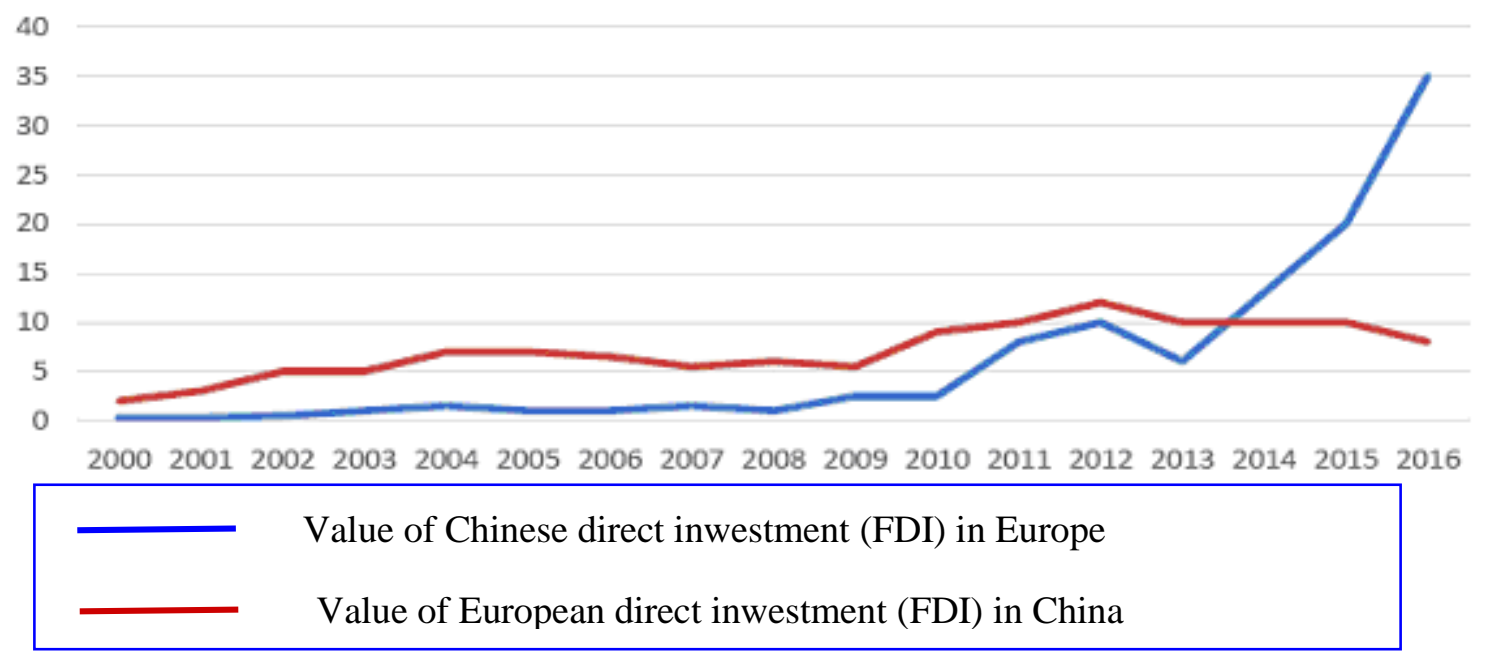

Fig. 4. EU-China mutual investment (in billion euros).

Source: [Hanemann and Houtari 2017].

Until the Chinese agree to improve access to their market and equal treatment of foreign companies, the lack of balance in mutual economic relations will be a serious barrier.

Table 3. Rail container trade between China and Europe in TEU.

\begin{tabular}{|c|c|c|c|c|c|c|c|}
\hline & 2011 & 2012 & 2013 & 2014 & 2015 & 2016 & 2017 \\
\hline From China to Europe & 1.404 & 3.674 & 6.960 & 23.804 & 47.132 & 97.400 & 212.000 \\
\hline From Europe to China & 0 & 0 & 0 & 2.266 & 21.770 & 48.394 & 105.930 \\
\hline $\begin{array}{c}\text { Difference in favor of } \\
\text { transport from China }\end{array}$ & 1.404 & 3.674 & 6.960 & 21.538 & 25.362 & 49.006 & 106.070 \\
\hline
\end{tabular}

Source: [Liu and Ke 2018].

A growing difference in the westbound and eastbound volume of rail container movement can be seen. What intensifies the situation is that $80 \%$ of the eastbound containers are unloaded, while $89 \%$ of westbound containers are loaded [Briginshaw 2018]. The train schedule for 2018 onward published by the rail freight operator China Railway Container Transport shows that there are 46 direct services for westbound rail freight transport and 19 services for eastbound shipment [Liu and Ke 2018]. These numbers prove the strong trade imbalance between China and Europe and risk of China's total dominance in economic relations.

\section{CONCLUSIVE REMARKS}

For China, the New Silk Road is not only an opportunity for further development, but also for expanding its sphere of influence and strengthening its position in the international arena. Problems also arise from Chinese territorial claims regarding the South China Sea area. Beijing is in dispute with the countries of the ASEAN community about archipelagos located in this area, explaining its expansion by the desire to ensure the safety of maritime transport, i.e. the 
maritime part of the Belt and Road. For these reasons, it is difficult to assess a project solely from a transport point of view. In the background lurk the fears of neighboring countries exacerbated by the authoritarian (distant from Western democracy) style of exercising power.

\section{REFERENCES}

Adamczyk M., Nowy jedwabny szlak jako próba stworzenia mocarstwa lądowego w myśl klasycznych teorii geopolitycznych, Kultura - Historia - Globalizacja 2017, nr 22.

Barisitz S., Radzyner A., The New Silk Road, part I:a stocktaking and economic assessment, Focus on European Economic Integration Q3/17, Oesterreichische Nationalbank, pp. 8-30.

Bloomberg, available at: https://www.bloomberg.com/opinion/articles/2018-11-05/trans-asian-railputs-china-on-a-belt-and-road-to-nowhere (access 25th of September 2019).

Briginshaw D., Can China - Europe rail freight continue to prosper without Chinese subsidies? International Railway Journal. October 30, 2018, available at: https://www.railjournal.com/in_depth/can-china-europe-rail-freight-continue-to-prosper-withoutchinese-subsidies (access 29th of September 2019).

Brugier C., China's way: the new Silk Road, European Union Institute for Security Studies, May 2014, iss. 14.

Chen J., Liang Q, Comparative Study on the "New Silk Road" Strategy Between China and the U.S., International Economic Research, Journal of Finance Research, Volume 02, Issue 01, January 2018.

Economist, available at: https://www.economist.com/business/2017/09/16/new-rail-routes-betweenchina-and-europe-will-change-trade-patterns (access 30th of September 2019).

Galushko D., 2016. Study on Corridors. OTIF, Berne.

Hanemann T., Houtari M., Record Flows and Growing Imbalances. Chinese Investmentin Europe in 2016, MERICS Papers on China, No. 3, January 2017. Available at: https://www.merics.org/sites/ default/files/2018-07/MPOC_3_COFDI_2017_web.pdf (access 25th of September 2019).

Jiang B., Li J., Gong Ch., Maritime Shipping and Export Trade on "Maritime Silk Road", The Asian Journal of Shipping and Logistics 34(2) (2018), pp. 83-90.

Kalwasiński M., „Pas i Szlak” - chińska pułapka kredytowa? Analiza, available at: https://www.bankier.pl/ wiadomosc/Pas-i-Szlak-chinska-pulapka-kredytowa-Analiza-7576219.html Kozieł H., Nowy Jedwabny Szlak jest pełen zasadzek, issued 19.08.2018, available at: https://www.parkiet.com/Gospodarka---Swiat/308199997-Nowy-Jedwabny-Szlak-jest-pelenzasadzek.html (access 30th of September 2019) 
Lain S., The Potential and Pitfalls of Connectivity along the Silk Road Economic Belt, in: China's Belt and Road Initiative and its impact in Central Asia, Washington, D.C.: The George Washington University, Central Asia Program, ed. Marlene Laruelle (2018).

Li Y., The greater Eurasian partnership and the Belt and Road Initiative: Can the two be linked?, Journal of Eurasian Studies 9 (2018), pp. 94-99.

Lin C., China's New Silk Road to the Mediterranean: The Eurasian Land Bridge and Return of Admiral Zheng He, ISPSW Strategy Series: Focus on Defense and International Security 49 (165/2011), pp. 1-23.

Liu Q., Ke L., One-Belt-One-Road policy implication on logistics route competition: Case study of China-Germany trade, Maritime Economics Research Center Hamburg Business School, University of Hamburg, Hamburg (2018).

Luo W., China Railway Express carries weight of expections. Telegraph (May 24, 2017). Available at: http://www.telegraph.co.uk/news/world/chinawatch/business/china-railway-express-freight/ (access 25th of September 2019).

Otsuka S., Central Asia's rail network and the Eurasian land bridge. Japan Railway \& Transport Review 28(9) (2001), pp. 42-49.

Sarvari B., Szeidovitz A., The Political Economics of the New Silk Road. Baltic Journal of European Studies 6(1) (2016), pp. 3-27.

Schramm H.-J., Zhang X., Eurasian Rail Freight in the One Belt One Road Era Conference Paper June 2018, Conference: NOFOMA (The Nordic Logistics Research Network) (2018), At Kolding, Denmark.

Sheu J.B., Kundu T., Forecasting time-varying logistics distribution flows in the One Belt-One Road strategic context, Transportation Research - Part E 117 (2018), pp. 5-22.

Song L., Vision and Actions on Jointly Building Silk Road Economic Belt and 21stCentury Maritime Silk Road. Belt and Road Portal (2015). Available at: https://eng.yidaiyilu.gov.cn/qwyw/qwfb/1084.htm (access 15th of September 2019).

Straits Times Geographics, available at: https://www.straitstimes.com/asia/china-makes-tracks-onmodern-silk-road (access 15th of September 2019).

Tian J., 2016. One Belt and One Road: Connecting China and the world. McKinsey \& Company, available at: http://www.mckinsey.com/industries/capital-projects-andinfrastructure/ourinsights/one-belt-and-one-road-connecting-china-and-the-world (access 15th of September 2019)

Tomański R., Czym jest chiński Nowy Jedwabny Szlak?, available at: https://businessinsider.com.pl/finanse/makroekonomia/nowy-jedwabny-szlak-najwazniejszainicjatywa-ekonomiczna-chin/2xstct6 (access 30th of March 2019). 
Van der Putten, F.P., Meijnders, M., China, Europe and the Maritime Silk Road. Clingendael, Netherlands Institute of International Relations, Den Haag (2015).

Woods R., Intermodal motion, Air Cargo World, No.10 (2015), pp. 36-38.

A. Kolinski et al. (eds.), Contemporary challenges in supply chains, Vol. 1, https://doi.org/10.17270/B.M.978-83-66017-88-7.3 